\title{
Prevalensi dan Evaluasi Kesesuaian Penggunaan Antibiotik pada Pasien dengan Infeksi Methicillin Resistant Staphylococcus Aureus di RSUP Dr. Soeradji Tirtonegoro Klaten
}

\author{
Prevalence and Evaluation of Suitability of Antibiotic use in Patients with \\ Methicillin Resistant Staphylococcus Aureus in RSUP Dr. Soeradji Tirtonegoro \\ Klaten
}

Atik Nuryah, Nunung Yuniarti, Ika Puspitasari*

Magister Farmasi Klinik, Fakultas Farmasi, Universitas Gadjah Mada

Corresponding author: Ika Puspitasari: ika.puspitasari@gmail.com

Submitted: 20-07-2019

Revised: 08-08-2019

Accepted: 08-08-2019

\begin{abstract}
ABSTRAK
Methicillin Resistant Staphylococcus aureus (MRSA) menjadi masalah kesehatan terkini di dunia terkait angka morbiditas dan mortalitas yang tinggi. Pola resistensi bakteri juga mengalami perubahan dari waktu ke waktu sehingga diperlukan data yang sistematis mengenai prevalensi dan pola kepekaan bakteri $S$. aureus untuk mencegah resistensi dan mendapatkan outcome klinik yang baik. Tujuan Penelitian ini adalah untuk mengetahui prevalensi MRSA dan kesesuaian penggunaan antibiotik terhadap outcome klinik pasien di RSUP Dr Soeradji Tirtonegoro Klaten. Penelitian ini menggunakan rancangan penelitian deskriptif dengan desain penelitian cohort study. Sebanyak 332 pasien yang terinfeksi $S$. aureus dan 31 pasien dengan infeksi MRSA untuk menentukan prevalensi MRSA, serta sebanyak 23 pasien untuk mengetahui hubungan kesesuaian penggunaan antibiotik terhadap outcome klinik pasien yang dianalisis dengan menggunakan Chi Square. Penelitian ini dilakukan di RSUP dr. Soeradji Tirtonegoro Klaten secara retrospektif periode Januari 2015 Desember 2018. Hasil prevalensi MRSA terus meningkat dari tahun 2015 hingga tahun 2018 yaitu $7,69 \%, 5,63 \%, 10,85 \%$, dan $12,94 \%$, sedangkan hasil analisis statistik menunjukkan tidak terdapat hubungan bermakna antara penggunaan antibiotik terhadap clinical outcome dan hasil analisis bivariat terhadap karakteristik pasien menunjukkan usia $(p=0,825)$, jenis kelamin $(p=0.144)$, ruang perawatan $(p=0,130)$, infeksi penyerta $(p=0,704)$, dan ruang perawatan $(p=0,602)$ juga tidak memiliki hubungan bermakna terhadap clinical outcome pada pasien dengan infeksi MRSA di RSUP Dr Soeradji Tirtonegoro Klaten.
\end{abstract}

Kata kunci: Evaluasi kesesuaian penggunaan antibiotik, MRSA, RSUP Dr. Soeradji Tirtonegoro Klaten.

\begin{abstract}
Methicillin Resistant Staphylococcus aureus (MRSA) is the latest health problem in the world regarding high morbidity and mortality. The pattern of bacterial resistance also changes the time pattern. Comprehensive data is needed and the sensitivity pattern of $S$. aureus bacteria to prevent resistance and get good clinical results. The purpose of this study was to determine the prevalence of MRSA and the suitability of antibiotic use to the clinical outcomes of patients at RSUP Dr Soeradji Tirtonegoro Klaten. This study used a descriptive analytic study design with a cohort study design. A total of 332 patients supported S. aureus and 31 patients with MRSA infection to determine the prevalence of MRSA, and as many as 23 patients to obtain a relationship of suitability of antibiotic use to the clinical results of patients analyzed using Chi Square. This research was conducted at RSUP dr. Soeradji Tirtonegoro Klaten retrospectively from January 2015 - December 2018. The results of the prevalence of MRSA continued to increase from 2015 to 2018, namely 7.69\%, 5.63\%, 10.85\%, and $12.94 \%$, based on the results of statistical analysis not related to the relationship between antibiotic use of clinical results and the results of bivariate analysis on patient characteristics based on age $(p=0.825)$, sex $(p=0.144)$, treatment room $(p=0.130)$, concomitant infections $(p=0.704)$,
\end{abstract}


and treatment room $(\mathrm{p}=0.602)$ also did not have a positive relationship to clinical outcomes in patients with MRSA infection at Dr Soeradji Tirtonegoro Klaten Hospital.

Keywords: Appropriate evaluation of antibiotic use, MRSA, Dr. RSUP Soeradji Tirtonegoro Klaten.

\section{PENDAHULUAN}

Methicillin Resistant Staphyloccus aureus (MRSA) merupakan penyakit infeksi yang akhirakhir ini sangat mengkhawatirkan karena prevalensinya yang cukup tinggi. Di RS Saiful Anwar Malang, isolat MRSA didapatkan pada tahun 2012 (45,3\%) sedangkan prevalensi terendah pada tahun 2013 (33,5\%) (Erikawati dkk., 2016). Kejadian yang ditakutkan oleh rumah sakit di seluruh dunia termasuk Indonesia adalah masalah serius mengenai MRSA, karena banyak patogen yang telah resisten terhadap methicillin dan juga berpotensi resisten terhadap antibiotik lain, sehingga berdampak pada tingginya biaya yang ditanggung dan meningkatnya angka morbiditas dan mortalitas. Antibiotik memiliki peranan penting di lingkungan rumah sakit terutama di ruangan rawat inap dan ruang intensif di mana banyak pasien menggunakan antibiotik, karena pengobatan dan pencegahan resistensi dapat berhasil dengan menggunakan antibiotik secara bijak. Penggunaan antibiotik yang tidak tepat bisa berakibat buruk pada pasien (Bhargava dkk., 2013).

Prevalensi infeksi MRSA berbeda-beda disetiap negara di Eropa. Pada tahun 2014 prevalensi MRSA telah menurun menjadi 0,9\%, yang sebelumnya pada tahun 2007 prevalensi MRSA di Belanda adalah 56\% dan di Rumania $17,4 \%$. Walaupun telah mengalami penurunan, masih ada 7 dari 29 negara yang memiliki angka prevalensi MRSA yang masih cukup tinggi yaitu 25\% (Hassoun dkk., 2017).

Staphylococcus aureus merupakan flora normal kulit namun bersifat patogen pada host yang rentan. Bakteri ini mampu menyebabkan berbagai infeksi supuratif dengan angka keparahan yang bervariasi pada jaringan lunak, jaringan tulang, organ pernafasan, serta jaringan endovaskuler yang menimbulkan manifestasi berbagai penyakit seperti furunkel, impetigo,osteomyelitis, tonsilitis, bronkitis, pneumonia, endokarditis, meningensefalitis, dan sepsis (Erikawati dkk., 2016).

Laporan tentang resistensi $S$. aureus terhadap berbagai jenis antibiotik terus bermunculan di berbagai tempat dari waktu ke waktu. Pada tahun 2014, dilakukan penelitian tentang pola kepekaan S. aureus di RSUP Dr.
Soeradji Tirtonegoro Klaten, dimana didapatkan $64,8 \%$ isolat telah resisten terhadap antibiotik tetrasiklin, 53,7\% resisten terhadap eritromisin, dan 40,7\% resisten terhadap kloksasilin (Kurniawan dkk, 2014). Sedangkan pada penelitian di Rumah Sakit Fatmawati Jakarta pada tahun 2001-2002, S. aureus ditemukan resisten terhadap antibiotik penisilin $G$, ampisilin, sulbenisilin, dan amoxicilin (Refdanita dkk, 2014). Resistensi S. aureus terhadap berbagai jenis antibiotik juga ditemukan di Laboratorium Kesehatan Provinsi Kalimantan Timur pada tahun 2013. Sebanyak $79,5 \%$ isolat dilaporkan resisten terhadap penisilin, 34,6\% resisten terhadap gentamisin, dan $33,3 \%$ resisten terhadap ciprofloxacin (Hilda dan Berliana, 2015). Resistensi terhadap berbagai agen antibiotik tersebut menimbulkan dampak negatif yang signifikan berupa peningkatan biaya terapi hingga resiko komplikasi yang bisa mengancam jiwa (Batabyal dkk., 2012).

Berdasarkan hal tersebut, maka perlu dilakukan suatu penelitian terbaru untuk memperoleh gambaran mengenai evaluasi kesesuaian penggunaan antibiotik dan outcome terapinya pada pasien dengan infeksi MRSA di RSUP Dr Soeradji Tirtonegoro Klaten.

\section{METODOLOGI \\ Rancangan Penelitian}

Penelitian ini merupakan penelitian deskriptif observasional, dengan metode penelitian cohort study. Pengambilan data dilakukan secara retrospektif dalam kurun waktu 4 tahun yaitu pada bulan Januari 2015Desember 2018. Data diambil dari Instalasi mikrobiologi dan sistem informasi manajemen rumah sakit (SIM RS) dengan melihat rekam medis pasien dengan infeksi MRSA di RSUP dr Soeradji Tirtonegoro Klaten yang memenuhi kriteria inklusi penelitian ini. Data yang diambil meliputi identitas, diagnosis, terapi, pemeriksaan mikrobiologi dan catatan perkembangan pasien.

\section{Subyek Penelitian}

Subyek penelitian ini adalah semua pasien yang terinfeksi $S$. aureus dan positif MRSA di RSUP Dr Soeradji Tirtonegoro Klaten 
Tabel I. Distribusi Karakteristik Pasien MRSA di RSUP Dr. Soeradji Tirtonegoro

\begin{tabular}{|c|c|c|}
\hline Karakteristik Pasien & Jumlah (n=23) & Persentase (\%) \\
\hline \multicolumn{3}{|l|}{ Usia: } \\
\hline 18-60 Tahun & 14 & 60.9 \\
\hline$>60$ tahun & 9 & 39.1 \\
\hline \multicolumn{3}{|l|}{ Jenis Kelamin: } \\
\hline Laki-laki & 16 & 69.6 \\
\hline Perempuan & 7 & 30.4 \\
\hline \multicolumn{3}{|l|}{ Ruang Perawatan: } \\
\hline ICU & 1 & 4.3 \\
\hline Non ICU & 22 & 95.7 \\
\hline \multicolumn{3}{|l|}{ Infeksi Penyerta: } \\
\hline Non Infeksi & 13 & 56.5 \\
\hline Infeksi & 10 & 43.5 \\
\hline \multicolumn{3}{|l|}{ Lama Perawatan: } \\
\hline$<7$ hari & 5 & 21.7 \\
\hline$\geq 7$ hari & 18 & 78.3 \\
\hline \multicolumn{3}{|l|}{ Outcome klinik: } \\
\hline Membaik & 20 & 87.0 \\
\hline Belum Membaik & 3 & 13.0 \\
\hline
\end{tabular}

periode bulan Januari 2015 hingga Desember 2018. Kriteria inklusi yang digunakan adalah rekam medis yang lengkap dan mendapatkan terapi antibiotik definitif. Pasien dengan MRSA yang tidak dapat diikuti riwayat pengobatannya karena hanya dilakukan screening atas permintaan dokter sebelum dilakuakn tindakan medis dieksklusi dari pemilitian ini.

\section{Tahapan Analisa :}

Tahap - tahap yang dilakukan dalam penyesuaian dosis obat sesuai fungsi ginjal adalah:

Menghitung prevalensi MRSA :

Jumlah seluruh isolat MRSA

Jumlah S.aureus+ MRSA

\section{$\mathrm{X} 100 \%$}

Menilai kesesuaian jenis antibiotik, dosis, frekuensi dan durasi yang diberikan pasien berdasarkan literatur : Drug Information, kemudian Handbook (DIH) edisi 26 th 2017 dan IDSA (2011).

\section{Observasi outcome clinic}

Observasi terhadap Outcome clinic meliputi target terapi yang harus dicapai dengan melihat pada rekam medis outcome clinic pasien membaik atau memburuk berdasarkan diagnosa dokter. Target terapi untuk setiap indikasi terapi obat meliputi parameter klinis yang ditetapkan dalam referensi. Parameter klinis ditentukan untuk setiap kondisi medis seperti angka leukosit, suhu, RR, kondisi klinis pasien. Pada penelitian ini dilakukan pengamatan outcome clinic pada pasien baik yang mendapatkan pengobatan dengan dosis yang tepat atau tidak. Parameter klinis yang dicapai pada akhir perawatan diamati untuk melihat hubungan kesesuaian antara pemberian antibiotik definitif terhadap clinical outcome.

\section{Analisis Data}

Analisis data secara deskriptif dilakukan untuk mengetahui prevalensi MRSA dan karakteristik pasien. Analisis statistik Chisquare digunakan untuk mengetahui hubungan kesesuaian antibiotik terhadap outcome clinic.

\section{HASIL DAN PEMBAHASAN}

Hasil analisis distribusi karakteristik pasien MRSA (Tabel I), di mana pasien MRSA di RSUP dr Soeradji Tirtonegoro Klaten tahun 2018 berusia antara 18-60 tahun yaitu sebesar $60,9 \%$ (14 pasien). Terjadinya MRSA dapat disebabkan penanganan yang kurang baik pada pasien dengan ulcus pedis dan infeksi pasca bedah ortopedi. Pembersihan luka yang kurang sempurna bisa mengakibatkan pertumbuhan bakteri yang tidak diinginkan. Rentang usia antara 18-60 merupakan usia produktif, dimana 
Atik Nuryah

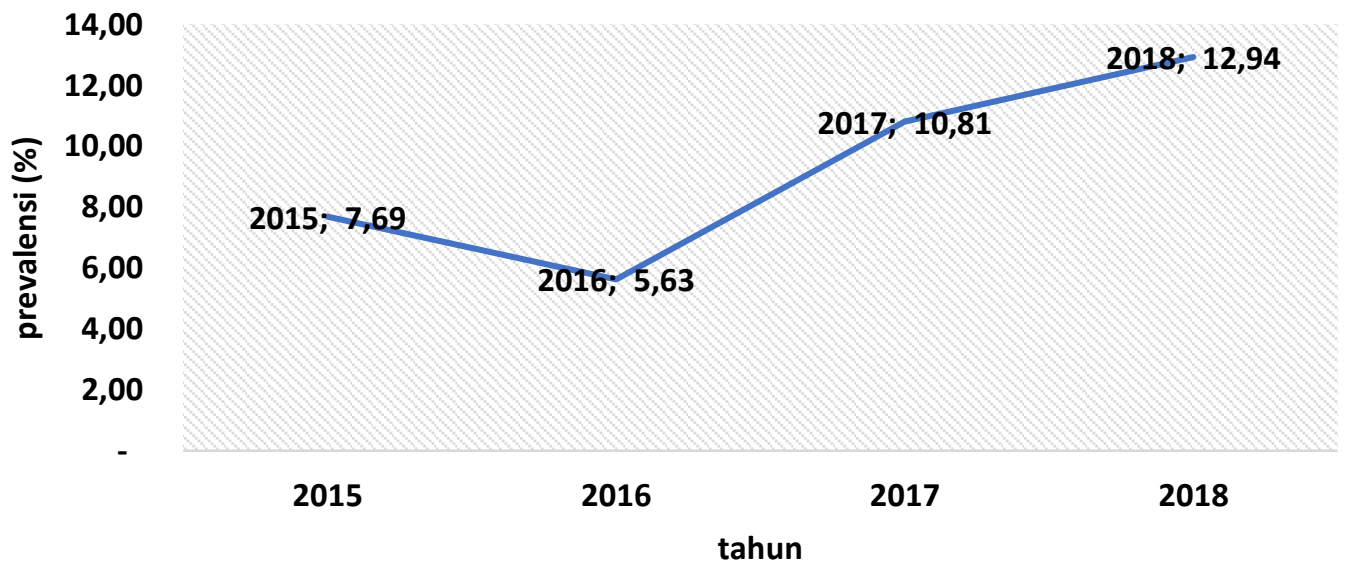

Gambar 2. Distribusi Prevalensi MRSA

pada rentang usia ini lebih banyak melakukan kegiatan atau aktivitas fisik seperti olahraga sehingga lebih berisiko terjadi cidera dan bisa menyebabkan ulkus pedis akibat adanya luka jika gula darah tidak terkontrol (Jacobus dkk., 2007).

Berdasarkan karakteristik jenis kelamin (Tabel I) menunjukkan bahwa mayoritas pasien MRSA di RSUP dr Soeradji Tirtonegoro Klaten adalah laki-laki yaitu sebesar 69,6\% (16 pasien) Laki-laki lebih rentan terhadap bakteri daripada wanita, faktor yang dapat mempengaruhi antara lain, laki-laki kurang patuh dalam memperbaiki perilaku kebersihan tangan, selain itu juga bisa peran olahraga serta pekerjaan dan hormon wanita seperti estrogen yang dapat mempengaruhi ekspresi faktor virulensi (Humphreys dkk., 2015).

Jika dilihat dari distribusi karakteristik pasien terlihat bahwa paling banyak pasien MRSA di RSUP dr Soeradji Tirtonegoro Klaten dirawat di ruang perawatan non ICU yaitu sebesar 95,7\% (22 pasien). Tingginya prevalensi pasien MRSA yang menerima perawatan di ruang non ICU ini dapat menjelaskan bahwa infeksi MRSA bukan dikarenakan pasien dengan kondisi klinik yang lemah atau penggunaan alat-alat medis yang lama, tetapi faktor angka kuman di bangsal rawat inap yang harus diperhatikan sehingga menurunkan angka resistensi antibiotik (Vahdani dkk, 2004).

Data analisis (Gambar 2) diperoleh hasil bahwa sebagian besar pasien MRSA di RSUP dr Soeradji Tirtonegoro Klaten telah menjalani perawatan lebih dari 7 hari yaitu sebesar 78,3\% (18 pasien). Pasien MRSA disertai dengan infeksi lain sebesar 43,5\% (10 pasien). Tingginya pasien MRSA yang menjalani perawatan lebih dari 7 hari walaupun tanpa infeksi penyerta lebih banyak, hal ini menunjukkan lamanya pengobatan akibat dari resistensi antibiotik. Pengobatan terapi infeksi dengan MRSA perlu diperhatikan pemberian antibiotik yang tepat sesuai indikasi dan penyakit penyerta sehingga jenis antibiotik, dosis obat, frekwensi serta durasi pengobatan sesuai dan dapat memberikan efek terapi yang optimal (Andreassen dkk., 2017). Kenyataan di lapangan banyak hasil kultur yang datang setelah pasien pulang sehingga dalam pemilihan antibiotik yang sesuai sulit karena dimungkinkan hasil kultur yang lama atau pemeriksaan kultur yang terlambat. Pada penelitian ini karakteristik subyek penelitian tidak menunjukkan perbedaan yang signifikan terhadap outcome clinic.

Dari data analisis Tablel 1 diperoleh hasil untuk pasien dengan penyakit penyerta non infeksi lebih banyak sehingga bisa disimpulkan pasien dengan MRSA bukan dengan riwayat penyakit yang berat sehingga hasil outcome clinic pasien membaik.

Hasil perhitungan prevalensi infeksi MRSA di RSUP Dr Soeradji Tirtonegoro Klaten, menunjukkan dari tahun 2015 hingga 2018 mengalami peningkatan. Data prevalensi MRSA pada tahun 2015 diketahui sebesar 7,69\%; dan menurun di tahun berikutnya yaitu sebesar 5,63\%. Meskipun sempat mengalami 
Prevalensi dan Evaluasi Kesesuaian Penggunaan Antibiotik

Tabel II. Hubungan Kesesuaian Penggunaan Antibiotik Terhadap Clinical Outcome Pasien MRSA

\begin{tabular}{|c|c|c|c|c|c|}
\hline \multirow{3}{*}{ Kesesuaian } & \multicolumn{4}{|c|}{ Clinical outcome } & \multirow{3}{*}{$\begin{array}{l}\text { Nilai } \\
\text { sig, }\end{array}$} \\
\hline & \multicolumn{2}{|c|}{ Membaik } & \multicolumn{2}{|c|}{ Belum Membaik } & \\
\hline & Jumlah & Persentase (\%) & Jumlah & Persentase (\%) & \\
\hline \multicolumn{6}{|l|}{ Jenis } \\
\hline Sesuai & 3 & 33,33 & 0 & 0 & 1,000 \\
\hline Tidak sesuai & 4 & 44,44 & 2 & 22,22 & \\
\hline \multicolumn{6}{|l|}{ Dosis } \\
\hline Sesuai & 5 & 55,6 & 1 & 11,1 & 1,000 \\
\hline Tidak sesuai & 2 & 22,2 & 1 & 11,1 & \\
\hline \multicolumn{6}{|l|}{ Frekuensi } \\
\hline Sesuai & 5 & 55,6 & 1 & 11,1 & 1,000 \\
\hline Tidak sesuai & 2 & 22,2 & 1 & 11,1 & \\
\hline \multicolumn{6}{|l|}{ Durasi } \\
\hline Sesuai & 6 & 66,7 & 1 & 11,1 & 0,417 \\
\hline Tidak sesuai & 1 & 11,1 & 1 & 11,1 & \\
\hline
\end{tabular}

penurunan infeksi MRSA akan tetapi pada tahun 2017 prevalensi MRSA kembali meningkat hingga mencapai 10,81\% dan kembali meningkat pada tahun 2018 yaitu sebesar $12,94 \%$. Hal ini seperti dengan penelitian di RS Saiful Anwar Malang bahwa angka prevalensi MRSA yang cukup tinggi (Erikawati dkk., 2016).

Peningkatan prevalensi MRSA tersebut dapat dicegah melalui beberapa upaya-upaya seperti menjaga kebersihan di seluruh area rumah sakit, cuci tangan dengan benar agar terhindar dari berbagai paparan bakteri (Ventola, 2015).

Dari analisa data pada (Tabel II) terkait gambaran dosis pemberian antibiotik definitif pada pasien dengan kasus delayed infected cruvit, implant failure dan infeksi MRSA yang mendapatkan kotrimoksazol dengan dosis, frekuensi, dan durasi yang sudah sesuai dengan guideline, sebelumnya mendapatkan injeksi meropenem, pada kasus ini pasien mengalami perbaikan klinis dan pada pasien dengan kasus selulittis pedis sinistra dan ulkus pedis DM menggunakan klindamisin juga memberikan outcome clinic yang membaik. Pemberian obat dengan jenis, dosis, frekuensi, dan durasi yang sesuai akan memberikan hasil terapi yang optimal. . Antibiotik definitif yang sering digunakan adalah kloramfenikol yaitu 33,3\% hal ini disebabkan bakteri sangat sensitif dengan antibiotik tersebut yang sudah sesuai dengan hasil kultur akan tetapi belum sesuai dengan guideline terapi untuk MRSA. Penggunan antibiotik kloramfenikol banyak digunakan dalam terapi definitif, antara lain diberikan pada kasus DM hiperglikemia dengan sepsis shock dan pasien ini pada akhirnya meninggal karena dengan kloramfenikol terapi antibiotik kurang adekuat. Kasus berikutnya adalah abses pelvis dan femur serta osteomyelitis tibia kronis dengan hasil outcome clinic pasien membaik. Pasien dengan outcome clinic membaik sedangkan pasien mendapatkan antibiotik bukan untuk terapi MRSA bisa disebabkan kolonisasi bakteri yang banyak adalah bakteri non MRSA sehingga dengan kloramfenikol pasien mengalami perbaikan klinis. Kasus lain terkait dengan kesesuaian terapi definitf yang tidak sesuai guideline MRSA tetapi memberikan outcome clinic membaik yaitu emphysema paru dextra dengan terapi levofloksasin dan pneumonia dengan terapi kotrimoksasol.

Data dalam Tabel II menunjukkan bahwa tidak terdapat hubungan yang bermakna antara jenis antibiotik $(p=1,000)$, dosis $(p=1,000)$, frekuensi $(p=1,000)$ serta durasi $(p=0,417)$ antibiotik definitif dengan clinical outcome pasien. Tidak adanya hubungan diantara keduanya disebabkan karena nilai signifikansi yang diperoleh lebih dari $\alpha 0,05$. Jika dilihat dari hasil analisis dapat diketahui juga bahwa dari 9 pasien yang mendapatkan antibiotik definitif, terdapat 3 pasien yang mendapatkan jenis antibiotik sesuai dengan kultur dan sesuai guideline MRSA. Adapun salah satu dari 3 pasien tersebut menggunakan antibiotik kotrimoksazol $480 \mathrm{mg} / 12$ jam selama 5 hari sedangkan 2 lainnya mendapatkan klindamisin 
saat pasien pulang dan mendapatkan clinical outcome yang membaik. Ketidaksesuaian jenis antibiotik dengan guideline MRSA tetapi sesuai dengan kultur bakteri ditemukan pada 3 pasien yaitu untuk penggunaan antibiotik jenis Sefepim dan Meropenem Levofloksasin infus, kloramfenikol injeksi dan Siprofloksasin. Pasien yang mendapatkan meropenem dan sefepim tidak mengalami perbaikan (meninggal) dengan LOS 23 hari. Hal ini bisa disebabkan penggunaan antibiotik untuk terapi MRSA belum sesuai guideline terapi MRSA sehingga pasien mengalami penurunan outcome clinic sedangkan untuk pasien yang mendapatkan levofloxacin infus mengalami perbaikan dengan LOS 10 hari dan pasien yang mendapatkan antibiotik siprofloksasin membaik dengan LOS 15 hari. Hal ini dimungkinkan bakteri yang banyak berkoloni bukan MRSA tetapi bakteri lain sehingga tanpa menggunakan antibiotik untuk MRSA pasien mengalami perbaikan klinis. Pasien yang menggunakan kloramfenikol dengan kasus DM hiperglikemia dan sepsis shock outcome clinic memburuk karena pemberian antibiotik dengan kloramfenikol saja kurang adekuat. Pasien yang menggunakan kloramfenikol injeksi dengan kasus abses pelvis dan emfisema paru mengalami perbaikan klinis.

Penggunaan antibiotik terutama untuk pasien dengan infeksi bakteri MRSA merupakan faktor penting yang harus diperhatikan, terutama dalam hal dosis antibiotik.

Berdasarkan hasil analisis yang telah dilakukan diperoleh data dari 9 pasien yang mendapatkan antibiotik definitif terdapat 6 pasien yang diberikan frekuensi durasi tidak tepat, dimana ada 1 pasien diantaranya memiliki clinical outcome belum membaik

Ketepatan frekuensi pemberian obat adalah batasan waktu pemberian antibiotik yang sesuai. Hal ini sangat berpengaruh pada efek terapi obat terutama pada obat-obat yang time dependent. Oleh karena itu pentingnya kesesuaian frekuensi harus diperhatikan untuk mencapai efek terapi yang optimal. Hasil analisis menunjukkan dari 9 pasien terdapat 6 pasien yang telah mendapatkan frekuensi pemberian antibiotik yang tepat, dengan 1 pasien yang dinyatakan memiliki clinical outcome belum membaik. Selanjutnya, sebanyak 3 pasien mendapat obat dengan frekuensi antibiotik yang tidak sesuai, dimana ada 1 pasien dinyatakan belum membaik. Ketidaksesuaian frekuensi antibiotik tersebut terdapat pada pasien yang mendapatkan (Sefepim dan Meropenem), pasien dengan Meropenem tunggal dan pasien dengan obat Kloramfenikol. Dari data tersebut diatas dapat disimpulkan tidak ada hubungan bermakna antara frekuensi obat dengan clinical outcome..

Ketidaksesuaian durasi obat dari hasil analisis menunjukkan ada 2 pasien yaitu pasien yang menggunakan kombinasi sefepim+meropenem dan obat tunggal meropenem. Dengan durasi yang tidak sesuai clinical outcome pasien ada yang membaik dan juga ada yang belum membaik. Durasi pemakaian antibiotik mempunyai batas waktu tertentu yang berbeda-beda tiap obatnya. Hal ini sangat penting diperhatikan untuk menghindari tejadinya resistensi bakteri akibat pemakaian antibiotik dengan durasi yang tidak tepat.

\section{KESIMPULAN}

Prevalensi MRSA terus meningkat di RSUP Dr Soeradji Tirtonegoro Klaten dari tahun 2015 hingga tahun 2018 yaitu 7,69\% di tahun 2015, 5,63\% (2016), 10,81\% (2017) dan $12,94 \%$ (2018). Pada penelitian ini tidak terdapat hubungan antara kesesuaianpenggunaan antibiotik dengan outcome clinic $(\mathrm{p}>0,05)$. Peran Farmasi Klinik perlu ditingkatkan dalam monitoring penggunaan obat sehingga didapatkan terapi yang rasional.

\section{UCAPAN TERIMA KASIH}

Penulis mengucapkan terimakasih kepada Badan Pengembangan dan Pemberdayaan Sumber Daya Manusia Kesehatan- Kementerian Kesehatan Republik Indonesia sebagai penyandang dana dalam penelitian ini.

\section{DAFTAR PUSTAKA}

Andreassen, A.E.S., Jacobsen, C.M., de Blasio, B., White, R., Kristiansen, I.S., dan Elstrøm, P., 2017. The impact of methicillin-resistant S. aureus on length of stay, readmissions and costs: a register based case-control study of patients hospitalized in Norway. Antimicrobial Resistance \& Infection Control, 6: .

Batabyal, B., Kundu, G.K.R., dan Biswas, S., 2012. Methicillin-Resistant Staphylococcus Aureus: A Brief Review 1: 7.

Bhargava, D., Deshpande, A., Sreekumar, K., Koneru, G., dan Rastogi, S., 2013. 
Guidelines of the Infectious Diseases Society of America for the Treatment of Methicillin-Resistant Staphylococcus aureus Infections: As Applied to Oral and Maxillofacial Clinical Practice. Journal of Maxillofacial and Oral Surgery, 12: 354358.

Erikawati, D., Santosaningsih, D., dan Santoso, S., 2016. Tingginya Prevalensi MRSA pada Isolat Klinik Periode 2010 - 2014 di RSUD Dr. Saiful Anwar Malang, Indonesia. Jurnal Kedokteran Brawijaya, 29: 149156.

Hassoun, A., Linden, P.K., dan Friedman, B., 2017. Incidence, prevalence, and management of MRSA bacteremia across patient populations-a review of recent developments in MRSA management and treatment. Critical Care, 21: .

Humphreys, H., Fitzpatick, F., dan Harvey, B.J.,
2015. Gender Differences in Rates of Carriage and Bloodstream Infection Caused by Methicillin-Resistant Staphylococcus aureus : Are They Real, Do They Matter and Why? Clinical Infectious Diseases, civ576.

Jacobus, C.H., Lindsell, C.J., Leach, S.D., Fermann, G.J., Kressel, A.B., dan Rue, L.E., 2007. Prevalence and demographics of methicillin resistant Staphylococcus aureusin culturable skin and soft tissue infections in an urban emergency department. BMC Emergency Medicine, 7:

Vahdani, P., Saifi, M., Aslani, M.M., Asarian, A.A., dan Sharafi, K., 2004. Antibiotic Resistant Patterns in MRSA Isolates from Patients Admitted in ICU and Infectious Ward 3: 37-43.

Ventola, C.L., n.d. The Antibiotic Resistance Crisis 7. 